Atmos. Chem. Phys., 13, 2471-2485, 2013

www.atmos-chem-phys.net/13/2471/2013/

doi:10.5194/acp-13-2471-2013

(C) Author(s) 2013. CC Attribution 3.0 License.

\title{
Global and regional temperature-change potentials for near-term climate forcers
}

\author{
W. J. Collins ${ }^{1}{ }^{*}$, M. M. Fry ${ }^{2}$, H. Yu ${ }^{3,4}$, J. S. Fuglestvedt ${ }^{5}$, D. T. Shindell ${ }^{6}$, and J. J. West ${ }^{2}$ \\ ${ }^{1}$ Met Office Hadley Centre, FitzRoy Road, Exeter, Devon, EX1 3PB, UK \\ ${ }^{2}$ Department of Environmental Sciences and Engineering, The University of North Carolina at Chapel Hill, 146B Rosenau \\ Hall, CB \#7431, Chapel Hill, North Carolina 27599, USA \\ ${ }^{3}$ Earth System Science Interdisciplinary Center, University of Maryland, College Park, Maryland, 20740, USA \\ ${ }^{4}$ Earth Science Directorate, NASA Goddard Space Flight Center, Greenbelt, Maryland, 20771, USA \\ ${ }^{5}$ Center for International Climate and Environmental Research - Oslo (CICERO), P.O. Box 1129 Blindern, \\ 0318 Oslo, Norway \\ ${ }^{6}$ NASA Goddard Institute for Space Studies, 2880 Broadway, New York, New York, 10025 USA \\ *now at: Department of Meteorology, University of Reading, P.O. Box 243, Reading, RG6 6BB, UK
}

Correspondence to: W. J. Collins (w.collins@ reading.ac.uk)

Received: 30 July 2012 - Published in Atmos. Chem. Phys. Discuss.: 7 September 2012

Revised: 26 January 2013 - Accepted: 20 February 2013 - Published: 5 March 2013

\begin{abstract}
We examine the climate effects of the emissions of near-term climate forcers (NTCFs) from 4 continental regions (East Asia, Europe, North America and South Asia) using results from the Task Force on Hemispheric Transport of Air Pollution Source-Receptor global chemical transport model simulations. We address 3 aerosol species (sulphate, particulate organic matter and black carbon) and 4 ozone precursors (methane, reactive nitrogen oxides $\left(\mathrm{NO}_{\mathrm{x}}\right)$, volatile organic compounds and carbon monoxide). We calculate the global climate metrics: global warming potentials (GWPs) and global temperature change potentials (GTPs). For the aerosols these metrics are simply time-dependent scalings of the equilibrium radiative forcings. The GTPs decrease more rapidly with time than the GWPs. The aerosol forcings and hence climate metrics have only a modest dependence on emission region. The metrics for ozone precursors include the effects on the methane lifetime. The impacts via methane are particularly important for the $20 \mathrm{yr}$ GTPs. Emissions of $\mathrm{NO}_{\mathrm{x}}$ and VOCs from South Asia have GWPs and GTPs of higher magnitude than from the other Northern Hemisphere regions.

The analysis is further extended by examining the temperature-change impacts in 4 latitude bands, and calculating absolute regional temperature-change potentials (ARTPs). The latitudinal pattern of the temperature response
\end{abstract}

does not directly follow the pattern of the diagnosed radiative forcing. We find that temperatures in the Arctic latitudes appear to be particularly sensitive to BC emissions from South Asia. The northern mid-latitude temperature response to northern mid-latitude emissions is approximately twice as large as the global average response for aerosol emission, and about $20-30 \%$ larger than the global average for methane, $\mathrm{VOC}$ and $\mathrm{CO}$ emissions.

\section{Introduction}

The emissions of reactive gases and aerosols can influence human and ecosystem health by affecting ozone and particulate matter concentrations (HTAP, 2010). They can also affect climate through the burdens of ozone, methane and aerosols, having both cooling and warming effects. Because of the short lifetimes of aerosols (days), ozone (weeks), methane (a decade), and their precursors, their climate effects are predominantly in the near term (less than $30 \mathrm{yr}$ ) so we refer to these species as "near-term climate forcers (NTCFs)". They are also often called short-lived climate pollutants (SLCPs).

UNEP and WMO (2011) and Shindell et al. (2012) have suggested that the mitigation of ozone precursors and black 
carbon (BC) would be attractive for both air quality and climate on a 30-yr timescale, provided it is not at the expense of $\mathrm{CO}_{2}$ mitigation. Typical air quality policies target both warming and cooling species and tend to have an overall detrimental effect on climate (in terms of surface temperatures). Therefore, it is important to understand how the effects of NTCFs vary by location of emissions, when air quality policies are considered. This can also be important for climate policies that affect both short and long-lived species (Berntsen et al., 2006). Many metrics have been proposed to compare these effects on climate, but here we consider the integrated radiative forcing (RF) using the global warming potential metric (GWP) (IPCC, 1990) and the surface temperature change using the global and regional temperaturechange metrics (GTP and RTP) (Shine et al., 2005; Shindell and Faluvegi, 2010).

The NTCFs we consider in this paper are sulphate, particulate organic matter (POM), black carbon (BC), methane and ozone precursors. Some halogenated species have short lifetimes and are therefore NTCFs, but we do not consider those here. NTCFs with lifetimes longer than the interhemispheric mixing time (such as methane) are considered reasonably well mixed, with the concentrations and RF patterns independent of the emission location. Species with shorter lifetimes such as ozone and aerosols have heterogeneous distributions and RF patterns that are dependent on the emission location (Fuglestvedt et al., 1999; Berntsen et al., 2005; Naik et al., 2005; Fry et al., 2012; Yu et al., 2013). The surface temperature response does not directly follow the spatial details of the RF pattern, rather it smoothes out the pattern over scales of $\sim 3500 \mathrm{~km}$ in the meridional direction and over $12000 \mathrm{~km}$ in the zonal direction (Shindell et al., 2010).

The RFs and GWPs for the Task Force on Hemispheric Transport of Air Pollution (HTAP) Source-Receptor global chemical transport model (CTM) simulations (HTAP, 2010) were previously documented by Fry et al. (2012) for reactive gases, and by Yu et al. (2013) for aerosols. In this study we have moved further down the chain of climate impacts, showing how analytical formulae can be used to relate equilibrium RF values to the evolution of global and latitudinal temperature changes.

We use the HTAP RF estimates to calculate GWPs in Sect. 3.1. From these, we derive the global mean surface temperature responses as functions of time for emissions of different components in different Northern Hemisphere regions, and normalise by the corresponding response for $\mathrm{CO}_{2}$ to derive GTPs in Sect. 3.2. Sections 3.1 and 3.2 follow a similar, but not identical methodology to Fuglestvedt et al. (2010). One difference being that for the ozone precursor reduction cases, we use experiments with fixed global methane concentrations; our calculations are based on RF and changes in methane lifetimes rather than the steady-state atmospheric concentrations and primary mode time constant that were used in Fuglestvedt et al. (2010). Then in Sect. 4, we go beyond looking at global mean values for the response and use the recently introduced concept of the RTP (Shindell and Faluvegi, 2010; Shindell et al., 2012) to quantify the impacts of regional pollutant emissions on temperatures in broad latitude bands.

\section{Methodology}

The basic data needed as input to the GWP and GTP calculations can be derived from the equilibrium RF responses of chemistry transport models to step changes in emissions. Here we use results from the HTAP study (HTAP, 2010) in which an ensemble of chemistry transport models carried out experiments reducing the emissions of (anthropogenic) ozone or aerosol precursors by $20 \%$ in four Northern Hemisphere continental regions (North America $\left[\mathrm{NA}, 15^{\circ}-55^{\circ} \mathrm{N}, 60^{\circ} \mathrm{W}-125^{\circ} \mathrm{W}\right.$ ], Europe [EU, $25^{\circ}-65^{\circ} \mathrm{N}$, $\left.10^{\circ} \mathrm{W}-50^{\circ} \mathrm{E}\right]$, East Asia [EA, $15^{\circ}-50^{\circ} \mathrm{N}, 95^{\circ}-160^{\circ} \mathrm{E}$ ], and South Asia [SA, $\left.\left.5^{\circ}-35^{\circ} \mathrm{N}, 50^{\circ}-95^{\circ} \mathrm{E}\right]\right)$. Each ozone precursor was reduced separately in each region. For the aerosol experiments, all species were reduced together. The effects of regional ozone precursor emission changes $\left(\mathrm{NO}_{\mathrm{x}}, \mathrm{CO}\right.$, NMVOCs, methane) on ozone and methane concentrations were calculated by Fiore et al. (2009). The consequent net RF impacts from an ensemble of 11 of the CTMs were calculated by Fry et al. (2012). The changes in RF due to the emissions of $\mathrm{SO}_{2}$, primary particulate organic matter (POM) and BC were calculated by Yu et al. (2013) from an ensemble of 9 models.

Because of the time needed for methane to equilibrate to emissions changes, methane concentrations were fixed globally to $1760 \mathrm{ppb}\left(\mathrm{nmol} \mathrm{mol}^{-1}\right)$ for all experiments except for the methane perturbation experiment in which it was reduced by $20 \%$ to $1408 \mathrm{ppb}$. The impacts of ozone precursor emissions on global methane and long-term ozone responses were calculated analytically from the methane loss by tropospheric OH diagnostic reported by each CTM (Fiore et al., 2009; Fry et al., 2012).

Fry et al. (2012) used the NOAA Geophysical Fluid Dynamics Laboratory (GFDL) standalone radiative transfer model (GFDL GAMDT, 2004) to calculate the gridded, stratospheric-adjusted net radiative fluxes (incoming shortwave minus outgoing longwave) at steady state due to changes in methane, ozone, and sulphate aerosol. The 3-D concentration fields were from the multi-model mean along with the mean \pm 1 standard deviation. The radiative transfer model simulations exclude aerosol-cloud interactions and the internal mixing of aerosols.

Yu et al. (2013) applied normalised direct RFs (NDRFs) calculated with the Goddard Chemistry Aerosol Radiation and Transport (GOCART) model (Yu et al., 2004) to the aerosol optical depths (AODs) from each model. The NDRFs were applied on a $2^{\circ} \times 2.5^{\circ}$ degree grid for each month of the year for each of the three components $\left(\mathrm{SO}_{4}, \mathrm{POM}, \mathrm{BC}\right)$. No aerosol-cloud interactions were included and the aerosols 
Table 1. Absolute global warming potentials (AGWPs) for emissions of $\mathrm{SO}_{2}$, POM and BC from the 4 HTAP continents, based on Table 6 of Yu et al. (2013). Units are $\mathrm{Wm}^{-2} \mathrm{yr} \mathrm{kg}^{-1}$. The AGWPs for aerosols are approximately independent of time horizon. Note these values exclude the effects of aerosol cloud interactions and the effect of BC deposition on snow albedo.

\begin{tabular}{lrrrrr}
\hline & EA & EU & NA & SA & All \\
\hline $\mathrm{SO}_{2}$ & $-2.9 \pm 0.8 \times 10^{-12}$ & $-3.9 \pm 0.7 \times 10^{-12}$ & $-3.9 \pm 0.8 \times 10^{-12}$ & $-3.9 \pm 1.0 \times 10^{-12}$ & $-3.5 \pm 0.8 \times 10^{-12}$ \\
$\mathrm{POM}$ & $-3.7 \pm 1.8 \times 10^{-12}$ & $-4.3 \pm 1.7 \times 10^{-12}$ & $-4.4 \pm 1.7 \times 10^{-12}$ & $-4.1 \pm 1.9 \times 10^{-12}$ & $-4.0 \pm 1.7 \times 10^{-12}$ \\
$\mathrm{BC}$ & $28 \pm 20 \times 10^{-12}$ & $37 \pm 19 \times 10^{-12}$ & $27 \pm 15 \times 10^{-12}$ & $25 \pm 15 \times 10^{-12}$ & $30 \pm 18 \times 10^{-12}$ \\
\hline
\end{tabular}

were assumed to be externally mixed in that the concentration of one did not affect the RF of another.

The basic quantities we take from these studies are the forcing efficiencies (RF change per unit emission rate change $\frac{F_{i}}{E_{i}}$ ) and (for the ozone precursors only) the changes in methane lifetime per unit emission rate $\left(\frac{\Delta \alpha_{i}^{\mathrm{CH}_{4}}}{E_{i}}\right) . F_{i}$ are the annual average changes in $\mathrm{RF}\left(\mathrm{Wm}^{-2}\right)$ following a change in emission rate of species $i$ by $E_{i}\left(\mathrm{~kg} \mathrm{yr}^{-1}\right)$, and $\Delta \alpha_{i}^{\mathrm{CH}_{4}}$ are the changes in the methane lifetime (yr). In Sect. 3 the global annual average forcing efficiencies from the tables in $\mathrm{Yu}$ et al. (2013) and Fry et al. (2012) are used; in Sect. 4 we expand on the results provided in these papers by splitting the forcing efficiencies into 4 latitude bands.

\section{Global metrics}

\subsection{Global warming potentials}

GWPs have been the most common way to compare the relative climate effects of different species. The absolute global warming potential (AGWP) is defined (IPCC, 1990) as the integrated RF over a time horizon $H$ due to a $1 \mathrm{~kg}$ pulse emission of a species and has units $\mathrm{Wm}^{-2} \mathrm{yr} \mathrm{kg}^{-1}$. For a species with an exponential decay with lifetime $\alpha$, $\operatorname{AGWP}(H)=A \alpha(1-\exp (-H / \alpha))$ where $A$ is the specific $\mathrm{RF}$ (RF per kg atmospheric burden). AGWP is typically normalised by the AGWP for $\mathrm{CO}_{2}$ to give a dimensionless quantity GWP. Here we use the $\mathrm{CO}_{2}$ impulse response function from the IPCC AR4 (Forster et al., 2007) where the RF from a pulse of $\mathrm{CO}_{2}$ is given by $A^{\mathrm{CO}_{2}}\left(a_{0}+\sum_{i=1}^{3} a_{i} \exp \left(-\frac{t}{\alpha_{i} \mathrm{CO}_{2}}\right)\right)$. $A^{\mathrm{CO}_{2}}$ is the radiative efficiency for $\mathrm{CO}_{2}$ in $\mathrm{Wm}^{-2} \mathrm{~kg}^{-1}$ $\left(1.82 \times 10^{-15} \mathrm{Wm}^{-2} \mathrm{~kg}^{-1}\right), a_{0-3}$ are unit less coefficients $[0.217,0.259,0.338$ and 0.186$]$, and $\alpha_{1-3}^{\mathrm{CO}_{2}}$ are $\mathrm{CO}_{2}$ response timescales [172.9, 18.51, 1.186] years. This gives AGWPs for $\mathrm{CO}_{2}$ of $2.5 \times 10^{-14}$ and $8.7 \times 10^{-14} \mathrm{Wm}^{-2} \mathrm{yr} \mathrm{kg}^{-1}$ at time horizons of 20 and $100 \mathrm{yr}$ respectively.

\subsubsection{Aerosols}

For the aerosol species, the lifetimes are sufficiently short that the atmospheric burdens rapidly reach equilibrium after a step change in emission. The equilibrium RFs, $F$ per emission change $E$ for each species $(F / E)$ (e.g. Table 6 of $\mathrm{Yu}$ et al. (2013)), are equal to $A \alpha$. Hence, provided that the time horizon chosen is much longer than the lifetime of the aerosol ( $\alpha \ll H$ ), the AGWP is also simply equal to the equilibrium response to a unit step change in emissions and is independent of the time horizon. A similar argument was made by Bond et al. (2011) where they introduced the specific forcing pulse (SFP) (units $\mathrm{J} \mathrm{kg}^{-1}$ ). For short-lived species $(\alpha \ll H)$ the global SFP is simply a scaling of the AGWP. We do not use the SFP concept further in this paper, but it is useful to illustrate that for short-lived species the AGWP can be considered an effectively instantaneous energy perturbation to the system.

The AGWP is a measure of the globally-averaged net radiative effect of an emission pulse, but the emissions themselves do not need to be globally emitted. Emissions from different regions have different lifetimes and the specific RFs may be regionally dependent. Both of these lead to a dependence of AGWP on the emitting region. AGWPs for $\mathrm{SO}_{2}$, POM and $\mathrm{BC}$ are listed for the 4 HTAP regions in Table 1; these are the same values as listed in Yu et al. (2013) Table 6 with a change of units. AGWPs for $\mathrm{SO}_{2}$ and POM are negative reflecting the cooling impact. The values for EA are slightly smaller than for the other continents due to more rapid removal of the aerosols and lower oxidation efficiency (Koch et al., 2007). Pollutants are typically exported from EA by frontal systems with associated strong precipitation (HTAP, 2010). In contrast, BC emissions have positive AGWPs, and the values for EU are slightly larger than for the other continents as these absorbing aerosols are advected over the brighter surfaces of the Arctic. The GWP values can be derived by normalising by the $\mathrm{AGWP}^{\mathrm{CO}_{2}}$ (see above), giving GWP(100)s of $-40 \pm 9,-46 \pm 20$, and $340 \pm 210$ for $\mathrm{SO}_{2}$, POM and BC, respectively for emissions from "All" regions. These are of slightly lower magnitude than in $\mathrm{Fu}$ glestvedt et al. (2010), but within the uncertainty ranges.

\subsubsection{Methane}

The decay time for a methane perturbation is around $12 \mathrm{yr}$, hence for time horizons of 20 or $30 \mathrm{yr}$, the criterion $(\alpha \ll H)$ no longer holds. For methane, the HTAP experiments were based on a global change in the methane concentration 
rather than regional emission changes to save running the chemistry models to equilibrium. Here the direct AGWP is again given by $\frac{F_{\mathrm{CH}_{4}}^{\mathrm{CH}_{4}}}{E^{\mathrm{CH}}}\left(1-\exp \left(-H / f \alpha^{\mathrm{CH}_{4}}\right)\right)$ where $F_{\mathrm{CH}_{4}}^{\mathrm{CH}_{4}}$ is the methane forcing diagnosed from the methane change experiment using the formula from Table 3 of Myhre et al. (1998). The factor $f$ accounts for the effect of methane on its own lifetime (Prather et al., 1996). The implied emissions necessary to cause this change in concentration are given by $E^{\mathrm{CH}_{4}}=\Delta B^{\mathrm{CH}_{4}} / f \alpha^{\mathrm{CH}_{4}}$ where $\Delta B^{\mathrm{CH}_{4}}$ is the change in methane burden. In the HTAP methane perturbation experiment (SR2) where methane was decreased by $20 \%$ from $1760 \mathrm{ppb}$ to $1408 \mathrm{ppb}, \Delta B^{\mathrm{CH}_{4}}=979 \mathrm{Tg}$, $\alpha^{\mathrm{CH}_{4}}=8.7 \pm 1.3 \mathrm{yr}, f=1.34 \pm 0.05$ (Fiore et al., 2009) giving an implied emission of $-84 \mathrm{Tg} \mathrm{yr}^{-1}$. Methane is an ozone precursor, it affects the oxidation rate of $\mathrm{SO}_{2}$ to sulphate aerosol, and it generates water vapour (only important in the stratosphere). The two indirect forcings due to changes in ozone $F_{\mathrm{CH}_{4}}^{\mathrm{O}_{3}}\left(20.5 \% \pm 1.5 \%\right.$ of $\left.F_{\mathrm{CH}_{4}}^{\mathrm{CH}_{4}}\right)$ and sulphate $F_{\mathrm{CH}_{4}}^{\mathrm{SO}_{4}}\left(-1.1 \% \pm 2.4 \%\right.$ of $\left.F_{\mathrm{CH}_{4}}^{\mathrm{CH}_{4}}\right)$ were calculated in Fry et al. (2012); we also assume a stratospheric water vapour forcing $F_{\mathrm{CH}_{4}}^{\mathrm{H}_{2} \mathrm{O}}$ equal to $15 \% \pm 10 \%$ of the direct methane forcing (Forster et al., 2007) giving a total indirect contribution of $34 \pm 10 \%$. Contributions from ozone changes above the tropopause are not include here (see Sect. 5.1). The total direct + indirect AGWP from methane (excluding $\mathrm{CO}_{2}$ ) is therefore

$$
\begin{aligned}
& \mathrm{AGWP} \mathrm{CH}_{4}= \\
& \left(F_{\mathrm{CH}_{4}}^{\mathrm{CH}_{4}}+F_{\mathrm{CH}_{4}}^{\mathrm{O}_{3}}+F_{\mathrm{CH}_{4}}^{\mathrm{SO}_{4}}+F_{\mathrm{CH}_{4}}^{\mathrm{H}_{4} \mathrm{O}}\right) \frac{f \alpha^{\mathrm{CH}_{4}}}{\Delta B^{\mathrm{CH}_{4}}}\left(1-\exp \left(-H / f \alpha^{\mathrm{CH}_{4}}\right)\right)
\end{aligned}
$$

\subsubsection{Ozone precursors}

Ozone precursors $\left(\mathrm{CO}, \mathrm{VOCs}\right.$ and $\mathrm{NO}_{\mathrm{x}}$ ) have a short-term impact on RF by generating ozone and perturbing sulphate oxidation; they also have a longer-term impact by changing the methane lifetime. The short-term impacts on ozone $F_{i}^{\mathrm{O}_{3}}$ and sulphate $F_{i}^{\mathrm{SO}_{4}}$ forcing are diagnosed from the equilibrium experiments perturbing emissions of species $i$ but holding methane fixed. For $\mathrm{H} \gg \alpha$, as for the aerosols, the AGWPs for the short-lived components are then simply $\left(F_{i}^{\mathrm{O}_{3}}+F_{i}^{\mathrm{SO}_{4}}\right) / E_{i}$. Although methane concentrations were fixed in these experiments, the longer-term impacts on methane can be diagnosed from the change in the fluxes through the $\mathrm{CH}_{4}+\mathrm{OH}$ reaction in the models. Changes in methane lifetime $\Delta \alpha_{i}^{\mathrm{CH}_{4}}$ are then calculated from the flux diagnostics. If the methane concentrations had not been fixed the methane burden would have responded to the changes in lifetime moving towards a new equilibrium burden of $\left(\frac{\Delta \alpha^{\mathrm{CH} 4}+\alpha^{\mathrm{CH} 4}}{\alpha^{\mathrm{CH}} 4}\right)^{f} B^{\mathrm{CH}_{4}}$ where $B^{\mathrm{CH}_{4}}$ is the unperturbed burden (4983 Tg in the HTAP study). For small perturbations, the impact of these methane lifetime changes on the methane burden can be shown to be equivalent to the impact of methane emissions of $\frac{\Delta \alpha^{\mathrm{CH}} 4}{\alpha^{\mathrm{CH}}} \frac{B^{\mathrm{CH}} 4}{\alpha^{\mathrm{CH}} 4}$. Since the response to methane emissions has already been derived $\left(\mathrm{AGWPCH}_{4}\right.$ ), the AGWP for ozone precursors including the short and longterm (methane related) components is given by

$\mathrm{AGWP}^{i}=\frac{1}{E_{i}}\left(F_{i}^{\mathrm{O}_{3}}+F_{i}^{\mathrm{SO}_{4}}\right)+\chi_{i} \operatorname{AGWP}^{\mathrm{CH}_{4}}(H)$,

where the scaling factor $\chi_{i}=\frac{1}{E_{i}} \frac{\Delta \alpha_{i}^{\mathrm{CH}_{4}}}{\alpha^{\mathrm{CH}_{4}}} \frac{B^{\mathrm{CH}_{4}}}{\alpha^{\mathrm{CH}_{4}}}$ represents the equivalent methane emission and the AGWPCH${ }^{C_{4}}$ implicitly includes the long-term ozone and sulphate responses. Note only the long-term components are functions of the time horizon. The GWPs at 20 and $100 \mathrm{yr}$ for the ozone precursors were presented by Fry et al. (2012), their Table S2.

\subsection{Global temperature-change potentials}

The GTP metric (Shine et al., 2005) is more closely related to observable climate impacts than the GWP, as it is calculated from temperature changes. The absolute global temperature-change potential (AGTP) is given by the surface temperature response following an instantaneous pulse emission. The global surface temperature responds to changes in the RF at the tropopause on a spectrum of timescales. We follow the same methodology in Fuglestvedt et al. (2010) and use a temperature response function that is the sum of two exponentials $R(t)=\sum_{j=1}^{2} \frac{c_{j}}{d_{j}} \exp \left(-\frac{t}{d_{j}}\right)$ where the coefficients $c_{j}$ and $d_{j}$ are the climate sensitivities and timescales of the two modes. From Boucher and Reddy (2008) we use $\left.\left.c_{1}=0.631 \mathrm{~K}\left(\mathrm{Wm}^{-2}\right)^{-1}\right), c_{2}=0.429 \mathrm{~K}\left(\mathrm{Wm}^{-2}\right)^{-1}\right)$, $\mathrm{d}_{1}=8.4 \mathrm{yr}, \mathrm{d}_{2}=409.5 \mathrm{yr}$, giving an equilibrium climate sensitivity of $\left.1.060 \mathrm{~K}\left(\mathrm{Wm}^{-2}\right)^{-1}\right)$ ( $3.9 \mathrm{~K}$ for $\mathrm{CO}_{2}$ doubling). The GTPs are constructed by normalising by the corresponding AGTP for $\mathrm{CO}_{2}$. For this we use the expression in Fuglestvedt et al. (2010) (their Eq. A3).

$$
\begin{aligned}
& \operatorname{AGTP}^{\mathrm{CO}_{2}}(H)=A^{\mathrm{CO}_{2}} \sum_{j=1}^{2}\left\{a_{0} c_{j}\left(1-\exp \left(-\frac{H}{d_{j}}\right)\right)+\right. \\
& \left.\sum_{i=1}^{3} \frac{a_{i} \alpha_{i}^{\mathrm{CO}_{2}} c_{j}}{\alpha_{i}^{\mathrm{CO}_{2}}-d_{j}}\left(\exp \left(-\frac{H}{\alpha_{i}^{\mathrm{CO}_{2}}}\right)-\exp \left(-\frac{H}{d_{j}}\right)\right)\right\}
\end{aligned}
$$

Using the $\mathrm{CO}_{2}$ radiative efficiency $\left(A^{\mathrm{CO}_{2}}\right)$ and the response parameters $a_{i}$ and $\alpha_{i}^{\mathrm{CO}_{2}}$ as described in Sect. 3.1 gives $\mathrm{AGTP}^{\mathrm{CO}_{2}}$ of $6.8 \times 10^{-16}$ and $5.1 \times 10^{-16} \mathrm{~K} \mathrm{~kg}^{-1}$ for 20 and $100 \mathrm{yr}$ time horizons respectively.

\subsubsection{Aerosols}

For aerosols with lifetimes much less than the time horizons of interest and the shortest climate timescale $\left(\alpha \ll H, \alpha \ll d_{1}\right)$ the AGTP is simply a scaling of the temperature response function by the equilibrium forcing from a unit step change 
Table 2. GTPs at 20 and $100 \mathrm{yr}$ time horizons for the HTAP aerosols (or precursors), methane and non-methane ozone precursors. Data are given for emissions from the 4 HTAP continents separately and combined. For methane only a global number is given. Uncertainties are intermodel differences in the CTM responses to emission perturbations from Yu et al. (2013) and Fry et al. (2012). This includes uncertainties in the aerosol and ozone responses, and in the methane lifetime response. Note these values exclude the effects of aerosol cloud interactions, the effect of BC deposition on snow albedo, changes in ozone above the tropopause and carbon-cycle interactions as described in Sect. 5.

\begin{tabular}{|c|c|c|c|c|c|}
\hline & EA & $\mathrm{EU}$ & NA & SA & All \\
\hline \multicolumn{6}{|c|}{ GTP(20) } \\
\hline $\mathrm{SO}_{2}$ & $-31 \pm 13$ & $-43 \pm 15$ & $-43 \pm 14$ & $-42 \pm 9$ & $-38 \pm 12$ \\
\hline POM & $-50 \pm 17$ & $-58 \pm 18$ & $-59 \pm 15$ & $-58 \pm 17$ & $-55 \pm 16$ \\
\hline $\mathrm{BC}$ & $410 \pm 350$ & $530 \pm 190$ & $400 \pm 150$ & $350 \pm 160$ & $420 \pm 190$ \\
\hline $\mathrm{CH}_{4}$ & & & & & $54.6 \pm 8.8$ \\
\hline $\mathrm{NO}_{\mathrm{x}}$ & $-55.6 \pm 23.8$ & $-48.0 \pm 14.9$ & $-61.9 \pm 27.8$ & $-124.6 \pm 67.4$ & $-62.1 \pm 26.2$ \\
\hline NMVOC & $8.4 \pm 4.6$ & $9.5 \pm 6.5$ & $8.6 \pm 6.4$ & $15.7 \pm 5.0$ & $10.0 \pm 5.7$ \\
\hline $\mathrm{CO}$ & $3.5 \pm 1.3$ & $3.2 \pm 1.2$ & $3.7 \pm 1.3$ & $3.4 \pm 1.0$ & $3.5 \pm 1.2$ \\
\hline \multicolumn{6}{|c|}{ GTP(100) } \\
\hline $\mathrm{SO}_{2}$ & $-4.1 \pm 1.6$ & $-5.7 \pm 2.0$ & $-5.7 \pm 1.8$ & $-5.5 \pm 1.1$ & $-5.1 \pm 1.6$ \\
\hline POM & $-6.7 \pm 2.0$ & $-7.7 \pm 2.4$ & $-7.8 \pm 2.0$ & $-7.7 \pm 2.3$ & $-7.3 \pm 2.1$ \\
\hline $\mathrm{BC}$ & $55 \pm 46$ & $71 \pm 25$ & $53 \pm 20$ & $46 \pm 21$ & $56 \pm 25$ \\
\hline $\mathrm{CH}_{4}$ & & & & & $3.6 \pm 1.2$ \\
\hline $\mathrm{NO}_{\mathrm{x}}$ & $-1.3 \pm 2.1$ & $-2.5 \pm 1.3$ & $-1.7 \pm 2.1$ & $-4.6 \pm 5.1$ & $-2.2 \pm 2.1$ \\
\hline NMVOC & $0.7 \pm 0.4$ & $0.8 \pm 0.5$ & $0.7 \pm 0.5$ & $1.3 \pm 0.5$ & $0.9 \pm 0.5$ \\
\hline $\mathrm{CO}$ & $0.26 \pm 0.12$ & $0.24 \pm 0.11$ & $0.27 \pm 0.12$ & $0.27 \pm 0.10$ & $0.26 \pm 0.11$ \\
\hline
\end{tabular}

in emission.

$A \operatorname{GTP}^{i}(H)=\frac{F_{i}}{E_{i}} R(H)=\mathrm{AGWP}^{i} \times R(H)$

The GTP is calculated by dividing this by $\mathrm{AGTP}^{\mathrm{CO}}{ }_{2}$. The GTPs for the 3 HTAP aerosol species from each of the 4 continents and combined ("All”) are shown in Fig. 1 for a $20 \mathrm{yr}$ time horizon. The values for a $100 \mathrm{yr}$ time horizon would have exactly the same pattern, but scaled by $\frac{R(100)}{R(20)} \times \frac{\mathrm{AGTP}^{\mathrm{CO}_{2}}(20)}{\mathrm{AGTP}^{\mathrm{CO}_{2}(100)}}(=0.138)$. GTPs for both time horizons are listed in Table 2 . The patterns are also the same as for the AGWPs in Table 1 and the forcing efficiencies in Table 6 of Yu et al. (2013).

\subsubsection{Methane}

For methane, the interactions between the methane lifetime and the climate response timescales become important. Combining the expression for the methane AGWP with equation A4 from Fuglestvedt et al. (2010) we get for the total AGTP:

$\operatorname{AGTP}^{\mathrm{CH}_{4}}(H)=\left(F_{\mathrm{CH}_{4}}^{\mathrm{CH}_{4}}+F_{\mathrm{CH}_{4}}^{\mathrm{O}_{3}}+F_{\mathrm{CH}_{4}}^{\mathrm{SO}_{4}}+F_{\mathrm{CH}_{4}}^{\mathrm{H}_{2} \mathrm{O}}\right) \frac{f \alpha^{\mathrm{CH}_{4}}}{\Delta B^{\mathrm{CH}_{4}}}$.

$\sum_{j=1}^{2} \frac{c_{j}}{f \alpha^{\mathrm{CH}_{4}}-d_{j}}\left(\exp \left(\frac{-H}{f \alpha^{\mathrm{CH}_{4}}}\right)-\exp \left(\frac{-H}{d_{j}}\right)\right)$

The $\mathrm{GTP}^{\mathrm{CH}_{4}}$ for 20 and $100 \mathrm{yr}$ are shown in Fig. 2 and are listed in Table 2. The decrease in GTP between 20 and $100 \mathrm{yr}$ is a factor of 15, much larger than for the aerosols, This is because the AGTPCH ${ }^{\mathrm{CH}_{4}}$ has not dropped off as quickly by year
20 as it did for the aerosols. The dominant contribution to the $\mathrm{GTP}^{\mathrm{CH}_{4}}$ uncertainty comes from the inter-model variability in the methane lifetime in the control run $\left(\alpha^{\mathrm{CH}_{4}}\right)$. The direct methane contribution to the $\operatorname{GTP}(20)$ and $\operatorname{GTP}(100)$ are in agreement with Boucher et al. (2009), however the ozone contribution is slightly lower here as discussed in Sect. 5.1.

\subsubsection{Ozone precursors}

The AGTPs for the other ozone precursor species can be calculated by combining the equilibrium responses with the effects on the methane lifetime to obtain an analogous expression to the AGWP:

$$
\operatorname{AGTP}^{i}(H)=\frac{1}{E_{i}}\left(F_{i}^{\mathrm{O}_{3}}+F_{i}^{\mathrm{SO}_{4}}\right) R(H)+\chi_{i} \operatorname{AGTP}^{\mathrm{CH}_{4}}(H)
$$

The time evolution of the total AGTPs therefore depends on the relative balance between the short and long-term components, i.e. the almost instantaneous change in ozone and the decadal timescale for changes in methane. Figure 3 shows the GTP for $\mathrm{NO}_{\mathrm{x}}$, NMVOC and $\mathrm{CO}$ emissions (summed over the 4 continents). For $\mathrm{NO}_{\mathrm{x}}$ emissions the long-term component acts in the opposite sense to the short-term because $\mathrm{NO}_{\mathrm{x}}$ emissions produce ozone, but decrease methane $\left(\chi_{i}\right.$ is negative). The AGTP starts positive, but becomes negative after 10 yr. For NMVOC and CO emissions the short-term and long-term components have the same sign (as they increase both ozone and methane), with the long-term component being relatively more important for CO. In all cases, the GTP is dominated by the long-term component from about $30 \mathrm{yr}$ 

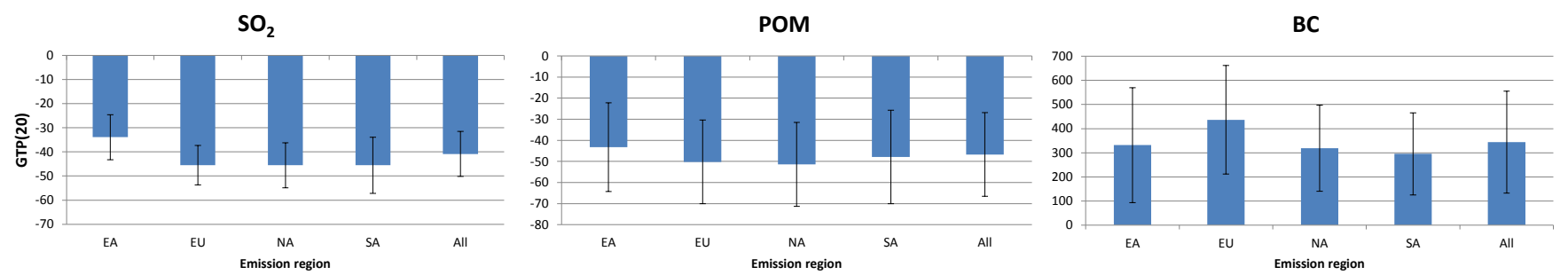

Fig. 1. $\mathrm{GTP}(20)$ for emissions of $\mathrm{SO}_{2}$, POM and $\mathrm{BC}$ from the four HTAP continents. Error bars reflect 1 s.d. uncertainty in the multi-model responses.

Table 3. Regional response coefficients in $\mathrm{K}\left(\mathrm{Wm}^{-2}\right)^{-1}$ for unit forcing from changes in $\mathrm{BC}$ and $\mathrm{O}_{3}$. Values are taken from Fig. 1 of Shindell and Faluvegi (2009). Data from $\mathrm{CO}_{2}$ changes are used for the $90^{\circ} \mathrm{S}-28^{\circ} \mathrm{S}$ forcing region. The $k_{l m}$ coefficients used in section 4 are derived by normalising these values by the climate sensitivity.

\begin{tabular}{|c|c|c|c|c|c|}
\hline \multirow{2}{*}{$\mathrm{BC}$} & & \multicolumn{4}{|c|}{ Forcing region } \\
\hline & & $90^{\circ} \mathrm{S}-28^{\circ} \mathrm{S}$ & $28^{\circ} \mathrm{S}-28^{\circ} \mathrm{N}$ & $28^{\circ} \mathrm{N}-60^{\circ} \mathrm{N}$ & $60^{\circ} \mathrm{N}-90^{\circ} \mathrm{N}$ \\
\hline \multirow{4}{*}{ Response region } & $90^{\circ} \mathrm{S}-28^{\circ} \mathrm{S}$ & 0.19 & 0.06 & 0.02 & 0.00 \\
\hline & $28^{\circ} \mathrm{S}-28^{\circ} \mathrm{N}$ & 0.09 & 0.17 & 0.07 & 0.02 \\
\hline & $28^{\circ} \mathrm{N}-60^{\circ} \mathrm{N}$ & 0.07 & 0.24 & 0.14 & 0.08 \\
\hline & $60^{\circ} \mathrm{N}-90^{\circ} \mathrm{N}$ & 0.06 & 0.31 & 0.15 & -0.08 \\
\hline \multirow{2}{*}{$\mathrm{O}_{3}$} & & \multicolumn{4}{|c|}{ Forcing region } \\
\hline & & $90^{\circ} \mathrm{S}-28^{\circ} \mathrm{S}$ & $28^{\circ} \mathrm{S}-28^{\circ} \mathrm{N}$ & $28^{\circ} \mathrm{N}-60^{\circ} \mathrm{N}$ & $60^{\circ} \mathrm{N}-90^{\circ} \mathrm{N}$ \\
\hline \multirow{4}{*}{ Response region } & $90^{\circ} \mathrm{S}-28^{\circ} \mathrm{S}$ & 0.19 & 0.13 & -0.06 & -0.03 \\
\hline & $28^{\circ} \mathrm{S}-28^{\circ} \mathrm{N}$ & 0.09 & 0.26 & 0.09 & 0.02 \\
\hline & $28^{\circ} \mathrm{N}-60^{\circ} \mathrm{N}$ & 0.07 & 0.15 & 0.20 & 0.06 \\
\hline & $60^{\circ} \mathrm{N}-90^{\circ} \mathrm{N}$ & 0.06 & 0.13 & 0.05 & 0.07 \\
\hline
\end{tabular}

to $60 \mathrm{yr}$. Beyond $60 \mathrm{yr}$ the short and long-term components are of similar magnitudes, although both are very small. The results of this can be seen in the bar charts of Fig. 4 and values listed in Table 2 which break the GTPs down by emission species and emission region. The net $\mathrm{NO}_{\mathrm{x}}$ GTPs are negative with the largest impact coming from emissions in SA, and the least impact from EU. For VOCs the largest impact is also from SA. The tropics are the region of greatest methane oxidation, so $\mathrm{NO}_{\mathrm{x}}$ and $\mathrm{VOC}$ emissions from SA have the largest impact on methane. CO has a sufficiently long lifetime that it can be advected away from the source continent; hence, the climate impact is largely independent of emission region. The fractional contribution to the GTP from the methane response is greater for the $20 \mathrm{yr}$ time horizon than the $100 \mathrm{yr}$ horizon. Although counterintuitive, the short-term contributions have already fallen rapidly by the $20 \mathrm{yr}$ horizon and the curves (Fig. 3) begin to flatten (decreases of a factor of 7 between 20 and $100 \mathrm{yr}$ ), whereas for the long-term contributions (driven by methane changes) the $20 \mathrm{yr}$ horizon is roughly in the steepest portion of the curve, declining thereafter by a factor of 15 by the $100 \mathrm{yr}$ horizon.

The error bars are a combination of the uncertainties in $F_{i}^{\mathrm{O}_{3}}, F_{i}^{\mathrm{SO}_{4}}, \alpha^{\mathrm{CH}_{4}}$, and $\Delta \alpha_{i}^{\mathrm{CH}_{4}}$ from the inter-model variability added in quadrature. The dominant contribution comes from the inter-model variability in the changes to the methane lifetime $\left(\Delta \alpha_{i}^{\mathrm{CH}_{4}}\right)$.

\section{Regional climate change}

Shindell and Faluvegi (2009), Shindell and Faluvegi (2010) and Shindell (2012) introduced the idea of the absolute regional temperature-change potential (ARTP) to quantify regional climate change from heterogeneous forcing patterns. There is not a one-to-one correspondence between the forcing in a region and the local temperature response, as there are RF contributions from outside the regions due to the transport of heat. Shindell and Faluvegi (2009) showed that the forcing-temperature relationship could be characterised using 4 broad latitude bands: southern mid-high latitudes $\left(90^{\circ} \mathrm{S}-28^{\circ} \mathrm{S}\right)$, tropics $\left(28^{\circ} \mathrm{S}-28^{\circ} \mathrm{N}\right)$, northern mid-latitudes $\left(28^{\circ} \mathrm{N}-60^{\circ} \mathrm{N}\right)$, and the Arctic $\left(60^{\circ} \mathrm{N}-90^{\circ} \mathrm{N}\right)$. Thus the expression for the AGTP can be generalised as:

$\operatorname{ARTP}_{m}(H)=\sum_{l} \int_{0}^{H} k_{l m} \frac{F_{l}(t)}{E} R(H-t) d t$ where $\mathrm{ARTP}_{m}$ is the temperature response in latitude band $m, k_{l m}$ are the response coefficients derived in Fig. 1 of Shindell and Faluvegi (2009) normalised by the climate sensitivity, and $F_{l}$ is the 

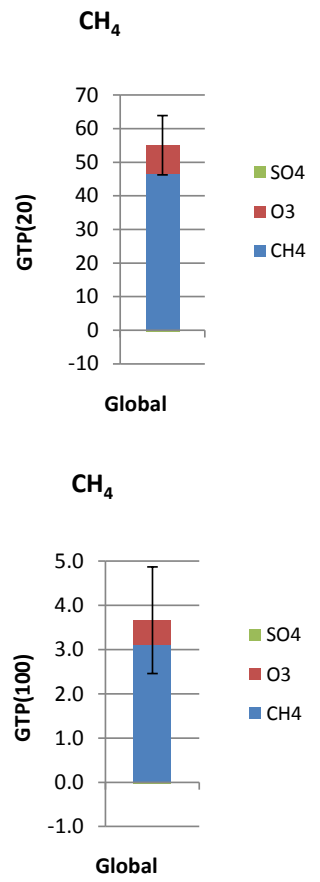

Fig. 2. GTP(20) and GTP(100) for global emissions of $\mathrm{CH}_{4}$. The GTPs are split according to the contributing components. The contribution from stratospheric water vapour is included in with $\mathrm{CH}_{4}$. Error bars reflect 1 standard deviation uncertainty in the multimodel responses.

tropopause RF in latitude band $l$ for a pulse emission $E$. For $\mathrm{SO}_{4}, \mathrm{POM}$ and $\mathrm{CH}_{4}$ we use the average $k_{l m}$ for $\mathrm{CO}_{2}$ and $\mathrm{SO}_{4}$ (Shindell and Faluvegi, 2010). For $\mathrm{BC}$ and $\mathrm{O}_{3}$ we use the $k_{l m}$ appropriate for the species except for responses to forcing in the $28^{\circ} \mathrm{S}-90^{\circ} \mathrm{S}$ band which was only derived for $\mathrm{CO}_{2}$ by Shindell and Faluvegi (2009). The coefficients used for $\mathrm{BC}$ and $\mathrm{O}_{3}$ are taken from Table 3, normalising by the climate sensitivity. We assume that the temperature response function $R$ applies equally to temperature changes in each region. As discussed in Shindell and Faluvegi (2010), in the different latitude bands encompassing such diverse regions as the Arctic and the tropics, the partitioning between the fast and slow responses and even the time constants of these responses may vary from the global average. There is no data currently available to break this down further, although Shindell (2012) suggests that the land response might be $20 \%$ larger than the average of land and ocean.

\subsection{Aerosols}

For aerosol emissions, the ARTPs have the same functional form as the AGTPs with the magnitudes given by the product of the response coefficients with the forcing pattern. The temperature change in latitude band $m$ due to the emission of species $i$ :

$\operatorname{ARTP}_{m}^{i}(H)=\sum_{l} \frac{F_{i, l}}{F_{i}} k_{l m} \operatorname{AGTP}^{i}(H)$

where $F_{i}$ is the equilibrium globally-average forcing as before, and $F_{i, l}$ is the RF averaged over latitude band $l$. The latitudinal patterns of the ARTPs for aerosols do not vary with time. Figure 5 shows the normalised equilibrium forcing patterns $\left(F_{i, l} / E_{i}\right)$ and the $\operatorname{ARTP}_{m}^{i}(20)$ values for the 3 aerosol species. Note that for the scattering aerosols $\left(\mathrm{SO}_{2}\right.$ and $\mathrm{POM}$ emissions) the largest RF is in the latitude band closest to the emitting region $\left(28^{\circ} \mathrm{N}-60^{\circ} \mathrm{N}\right.$ for EA, EU and NA emissions, $28^{\circ} \mathrm{S}-28^{\circ} \mathrm{N}$ for SA emissions). There seems to be very little RF from scattering aerosols over the bright Arctic latitudes as there is less contrast between the brightness of the aerosol and the underlying albedo. For the absorbing aerosol (BC), due to the high contrast, the RF is high over the Arctic latitudes, and for EU emissions the Arctic RF exceeds that of the northern mid-latitudes. Applying the matrix of response coefficients smoothes out the impacts such that there is less latitudinal variation in the temperature responses than in the RFs. The Arctic temperatures are particularly sensitive to forcing changes in the northern mid-latitudes (at least in the coefficient set used here), where the Arctic responses to the scattering aerosols are comparable to the northern midlatitude responses.

For BC the Arctic shows a lower surface temperature response than would be expected from the RF pattern. This is because for $\mathrm{BC}$ the $k_{l m}$ are negative for the Arctic response to Arctic forcing (see Table 3), i.e. a positive RF over the Arctic due to changes in atmospheric $\mathrm{BC}$ has a cooling effect on Arctic temperatures (figure 1d of Shindell and Faluvegi 2009). This relationship, while surprising, has been confirmed by other studies (Sand et al., 2013; Flanner, 2013) and is caused primarily by a decrease in the meridional heat transport. The Arctic cooling effect only applies to BC changes in the mid to upper Arctic troposphere, such as found here following advection from northern mid-latitude and tropical sources. Local Arctic emission of BC has a warming effect, as does deposition of $\mathrm{BC}$ on to Arctic snow from any source region (Flanner, 2013). The net effect on the Arctic of BC emissions is still warming from each of the HTAP regions since RF changes in the northern mid-latitudes and tropics have a large positive impact on Arctic temperatures by increasing the meridional heat transport. In fact in this study BC emissions from SA have the largest impact on Arctic temperatures since they exert a strong RF over the tropics and northern mid-latitudes and little over the Arctic. The responses in the Arctic to $\mathrm{BC}$ emissions might be expected to be more sensitive to the more northerly source regions if $\mathrm{BC}$ deposition to snow were accounted for.

The ARTP(20) values are shown, but the latitudinal patterns will be identical for any time horizon, albeit with different overall scaling. The aerosol impacts on the northern 

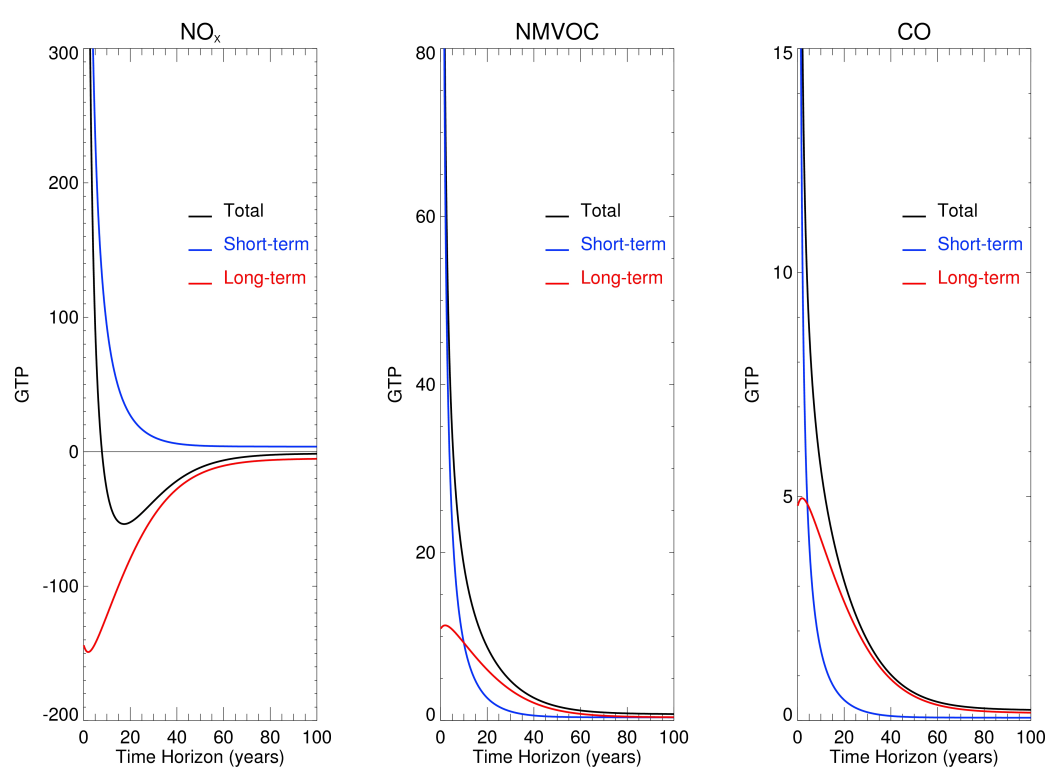

Fig. 3. GTPs as functions of time horizon for emissions of $\mathrm{NO}_{\mathrm{x}}$, NMVOC and $\mathrm{CO}$ from all 4 continents combined. The short and long-term components are also shown.

$\mathrm{NO}_{\mathrm{x}}$

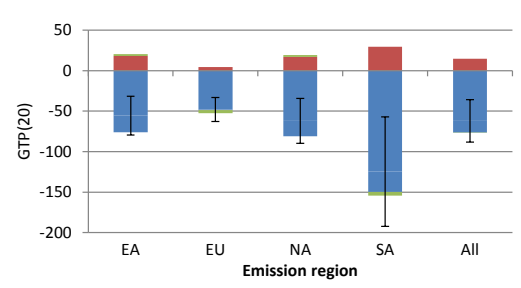

$\mathrm{NO}_{\mathrm{x}}$

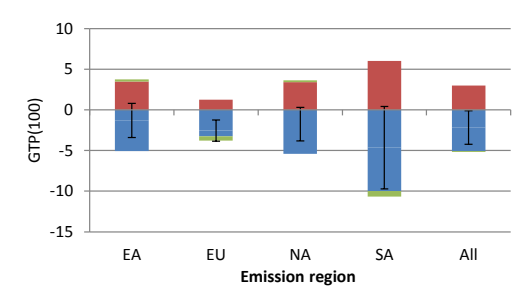

voc

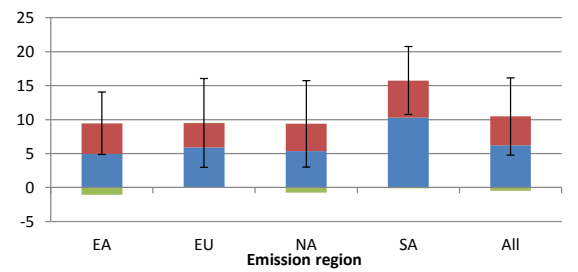

Voc

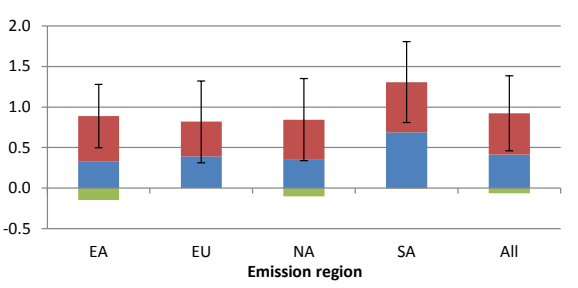

co

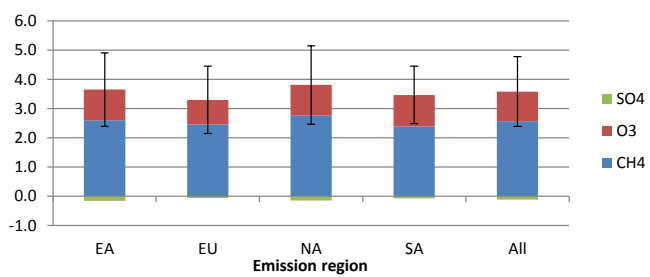

CO

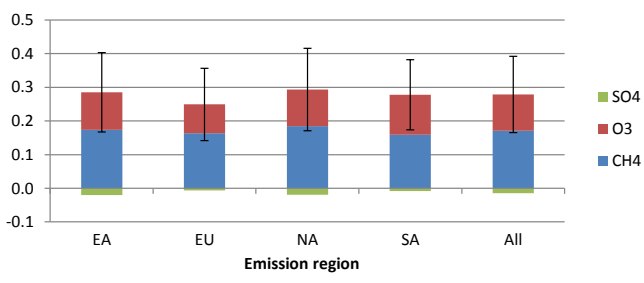

Fig. 4. GTP(20) and GTP(100) for emissions of $\mathrm{NO}_{\mathrm{x}}$, VOC and $\mathrm{CO}$ from the four HTAP continents separately and combined ("All”). The GTPs are split according to the contributing components. For $\mathrm{O}_{3}$ and $\mathrm{SO}_{4}$ these combine both the short and long-term components. The contribution from stratospheric water vapour is included in with $\mathrm{CH}_{4}$. Error bars reflect 1 standard deviation uncertainty in the multi-model responses.

latitudes are up to twice that implied just using the global average response. The "global" ARTP bars are calculated from an area-weighted average of the responses in the 4 latitude bands. These are slightly larger than the calculated AGTPs in the previous section, which implicitly used global averaged climate sensitivity. This difference can be considered as an efficacy larger than unity due to the forcing being concentrated at the higher northern latitudes where the climate response is stronger.

\subsection{Methane}

Analogous to the aerosols, for methane

$\operatorname{ARTP}_{m}^{\mathrm{CH}_{4}}(H)=\sum_{l} \frac{F_{\mathrm{CH}_{4}, l}}{F_{\mathrm{CH}_{4}}} k_{l m} \operatorname{AGTP}^{\mathrm{CH}_{4}}(H)$

where $F_{\mathrm{CH}_{4}, l}=F_{\mathrm{CH}_{4}, l}^{\mathrm{CH}_{4}}+F_{\mathrm{CH}_{4}, l}^{\mathrm{O}_{3}}+F_{\mathrm{CH}_{4}, l}^{\mathrm{SO}_{4}}$, noting that the direct methane forcing and indirect forcings through ozone and sulphate will have different latitudinal distributions. We do 


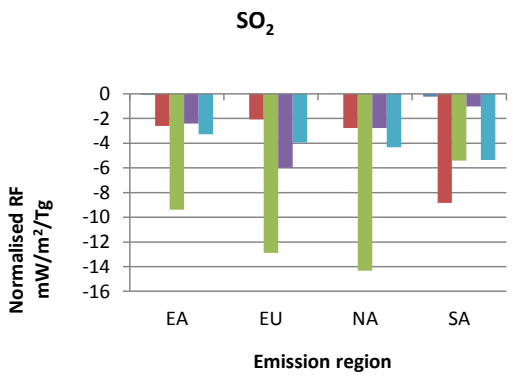

$\mathrm{SO}_{2}$

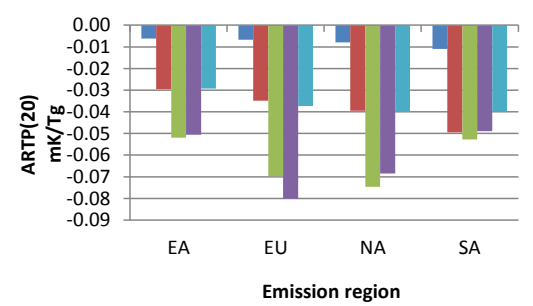

POM

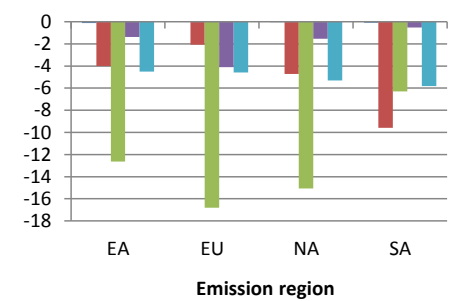

POM

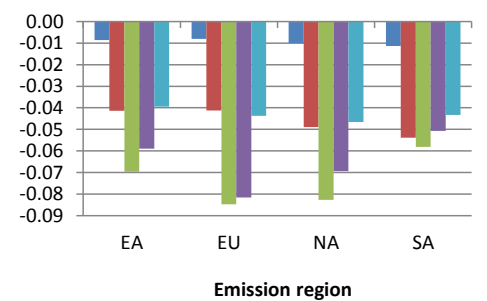

BC

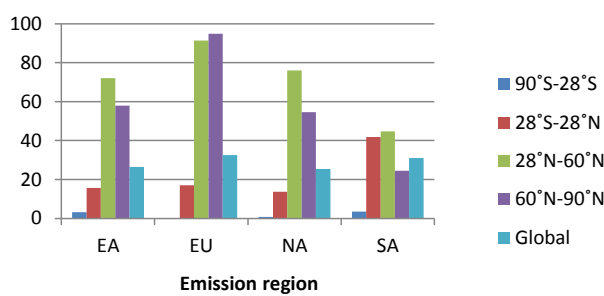

$\mathrm{BC}$

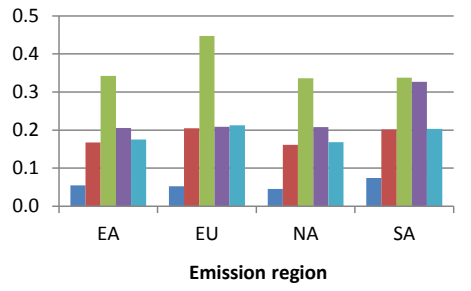

a $90^{\circ} \mathrm{S}-28^{\circ} \mathrm{S}$

$=28^{\circ} \mathrm{S}-28^{\circ} \mathrm{N}$

$=28^{\circ} \mathrm{N}-60^{\circ} \mathrm{N}$

$=60^{\circ} \mathrm{N}-90^{\circ} \mathrm{N}$

- Global

Fig. 5. Normalised equilibrium forcing in $\mathrm{mW} \mathrm{m}^{-2} \mathrm{Tg}^{-1}$ (upper panel) and ARTP(20) in $\mathrm{mK} \mathrm{Tg}^{-1}$ (lower panel) for emissions of SO 2 , $\mathrm{POM}$ and $\mathrm{BC}$ from the four HTAP continents. The coloured columns represent the forcing and temperature response in 4 different latitude bands $\left(90^{\circ} \mathrm{S}-28^{\circ} \mathrm{S}, 28^{\circ} \mathrm{S}-28^{\circ} \mathrm{N}, 28^{\circ} \mathrm{N}-60^{\circ} \mathrm{N}, 60^{\circ} \mathrm{N}-90^{\circ} \mathrm{N}\right)$ and globally.

not include the stratospheric water vapour forcing here as we have no information on its latitudinal profile. The RF and ARTP distributions are shown in Fig. 6. For methane, the forcings are more evenly distributed as methane is wellmixed, with the maximum RF in the tropics, but a significant RF in both the southern and northern extra-tropics. The ARTPs show less temperature response in the southern extra-tropics as this region is less sensitive to RF changes outside these latitudes. As for the aerosols, the latitudinal pattern of the temperature response to methane emissions does not vary with time.

\subsection{Ozone precursors}

For non-methane ozone precursors, the ARTPs are a combination of two functional forms:

$\operatorname{ARTP}_{m}^{i}(H)=$

$\frac{1}{E_{i}} \sum_{l}\left(k_{l m}\left(F_{i, l}^{\mathrm{O}_{3}}+F_{i, l}^{\mathrm{SO}_{4}}\right)\right) R(H)+\chi_{i} \operatorname{ARTP}_{m}^{\mathrm{CH}_{4}}(H)$

Here because the latitudinal patterns of the $F_{i, l}$ and $F_{\mathrm{CH}_{4}, l}$ are different the overall spatial pattern of the ARTP does evolve over time.

Figure 7 shows the latitudinal components of the forcing patterns for each ozone precursor from each region. The top panel shows the normalised short-lived equilibrium forcing terms $\left(F_{i, l}^{\mathrm{O}_{3}}+F_{i, l}^{\mathrm{SO}_{4}}\right) / E_{i}$. The lower panel shows the total equilibrium forcing patterns including the longterm component due to changes in the methane lifetime
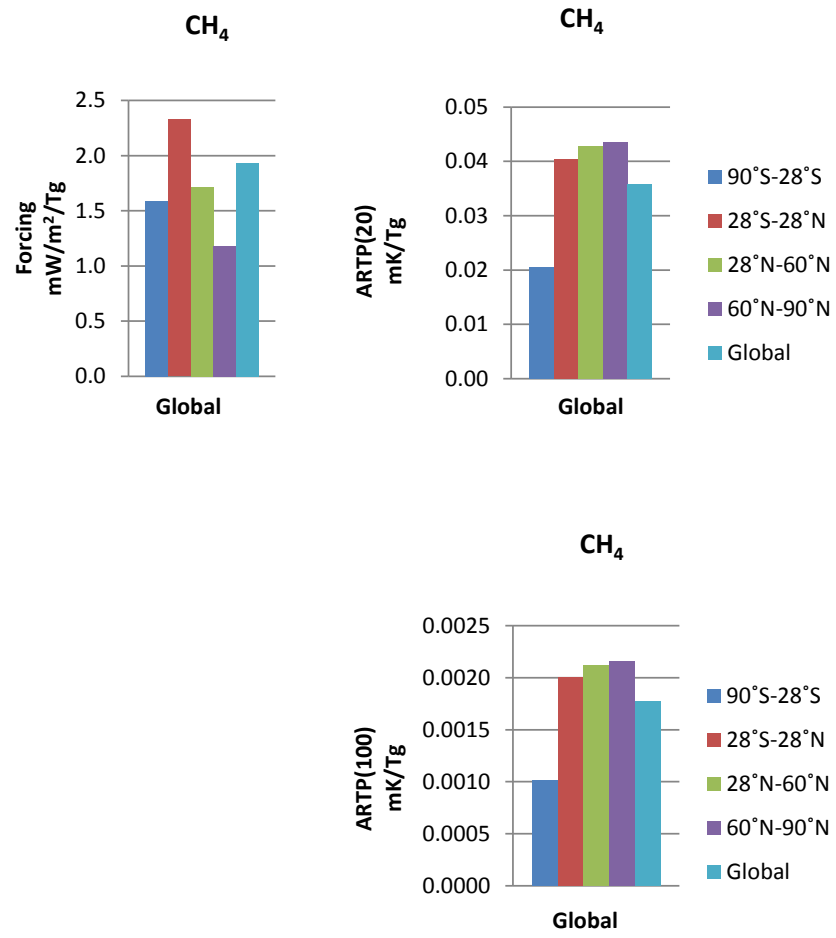

Fig. 6. Normalised equilibrium forcing in $\mathrm{mW} \mathrm{m}^{2} \mathrm{Tg}^{-1}$ (left), and ARTPs 20 and 100 (right), for global emissions of $\mathrm{CH}_{4}$. The coloured columns represent the forcing and temperature responses in 4 different latitude bands $\left(90^{\circ} \mathrm{S}-28^{\circ} \mathrm{S}, 28^{\circ} \mathrm{S}-28^{\circ} \mathrm{N}, 28^{\circ} \mathrm{N}-\right.$ $60^{\circ} \mathrm{N}, 60^{\circ} \mathrm{N}-90^{\circ} \mathrm{N}$ ) and globally. 


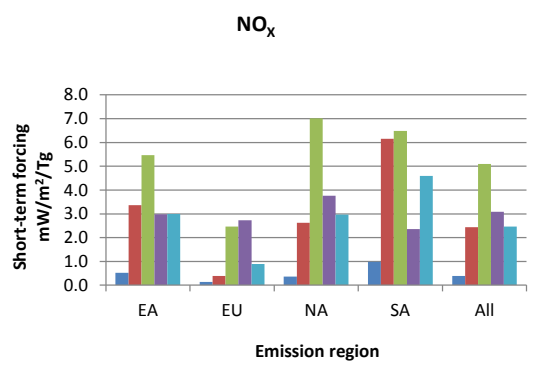

$\mathrm{NO}_{\mathrm{x}}$

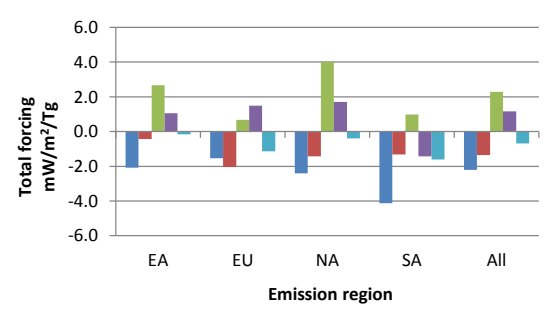

VOC

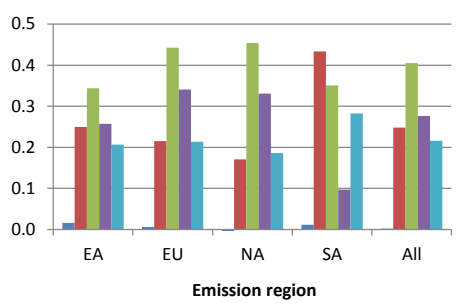

Voc

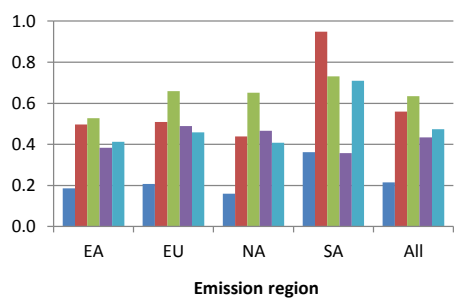

co

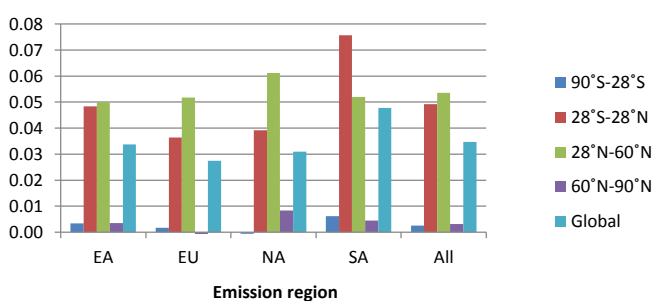

CO

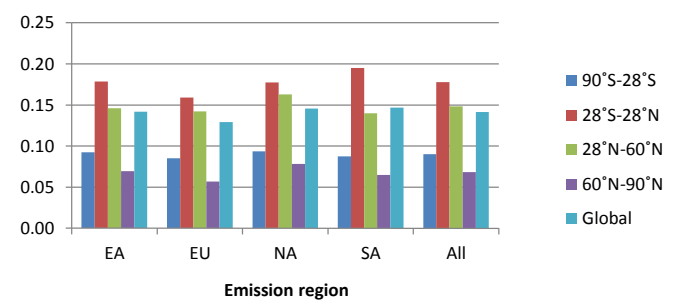

Fig. 7. Short-term (upper) and total (lower) normalised equilibrium forcing in $\mathrm{mW} \mathrm{m}{ }^{-2} \mathrm{Tg}^{-1}$ for emissions of $\mathrm{NO}_{\mathrm{x}}$, VOC and $\mathrm{CO}$ from the four HTAP continents. The coloured columns represent the forcing in 4 different latitude bands $\left(90^{\circ} \mathrm{S}-28^{\circ} \mathrm{S}, 28^{\circ} \mathrm{S}-28^{\circ} \mathrm{N}, 28^{\circ} \mathrm{N}-60^{\circ} \mathrm{N}\right.$, $60^{\circ} \mathrm{N}-90^{\circ} \mathrm{N}$ ) and globally.

$\left(F_{i, l}^{\mathrm{O}_{3}}+F_{i, l}^{\mathrm{SO}_{4}}\right) / E_{i}+\chi_{i} F_{\mathrm{CH}_{4}, l}$ along with the forcing pattern for methane itself. The RFs depend on the latitude of the emissions, with the highest short-term forcing in the northern mid-latitudes for emissions from EA, EU and NA, and in the tropics for emissions from SA. For $\mathrm{NO}_{\mathrm{x}}$, the $\chi_{i}$ are negative (reduced methane) so the net forcing is the difference between short and long-term components. The net forcings are negative in the Southern Hemisphere and tropics where methane destruction outweighs the ozone production, but positive in the northern mid and high latitudes (except for SA emissions which have negative forcing in the northern high latitudes). For NMVOC and CO emissions, the $\chi_{i}$ are positive (increased methane) so the long and short-term components add. When adding the smoother methane terms, the latitudinal distributions for the total forcing become more even than for the short-term components. For $\mathrm{CO}$, the highest forcing is in the tropics for all emission regions.

The corresponding ARTPs are shown in Fig. 8. For the ARTP(20)s, the long-term component is more important than the short-term component and the ARTPs for the nonmethane ozone precursors look similar to the methane ARTP, with an opposite sign for $\mathrm{NO}_{\mathrm{x}}$ emissions. The highest response is in the northern mid-latitudes for VOCs and CO. For the ARTP(100) the contributions of the short and long-term components are more balanced. For $\mathrm{NO}_{\mathrm{x}}$ the $\operatorname{ARTP}(100)$ s are close to zero in the northern mid-latitudes for emissions from EA and NA reflecting the warming from ozone balancing the cooling from decreased methane.

All the results from HTAP were based on changing Northern Hemisphere emissions. We do not have results from
Southern Hemisphere experiments, but might expect the forcing and temperature responses to be stronger in the hemisphere in to which the species are emitted.

\section{Limitations and uncertainties}

We acknowledge limitations to this study in this section, most importantly the neglect of the aerosol-cloud interactions. As a consequence, care must be taken in using some of the numerical values presented in Table 2.

\subsection{Changes in stratospheric ozone}

As previously discussed in Fry et al. (2012) the ozone forcing here only includes ozone changes below the tropopause. Søvde et al. (2012) calculate a forcing contribution from ozone responses above the tropopause of $15 \%$ of the total. Adding this would take the ozone contribution to the methane metrics to $24 \%$ of the direct methane effect. This ends up being a similar value to the $25 \pm 15 \%$ often used (e.g. Forster et al., 2007) which came originally from the troposphere-only responses of a mixture of 2-D and 3-D models discussed in chapter 2 of IPCC (1994).

\subsection{Aerosol interactions with clouds and snow albedo}

The responses to aerosol emission changes were calculated using chemical transport models that omit interactions with clouds, so the RFs presented here only include direct effects based on the aerosol column loadings (Yu et al., 2013). The indirect effects of aerosols are likely to be as great as the 
$\mathrm{NO}_{\mathrm{x}}$

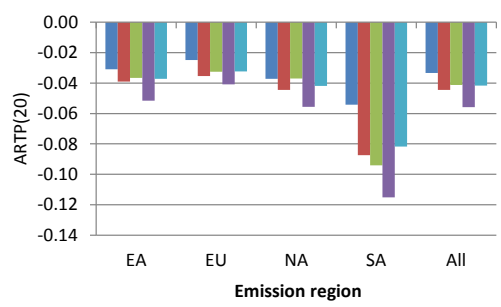

$\mathrm{NO}_{\mathrm{x}}$

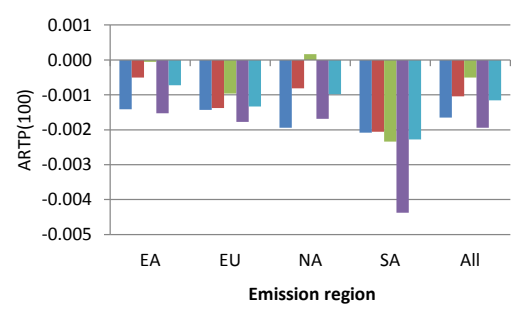

voc

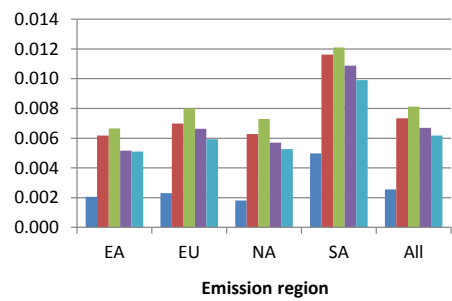

voc

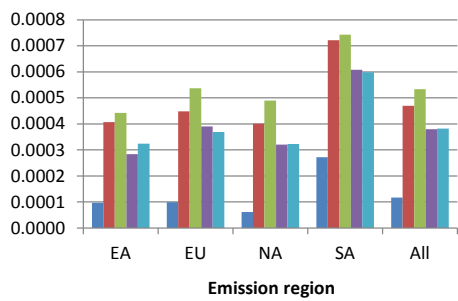

CO

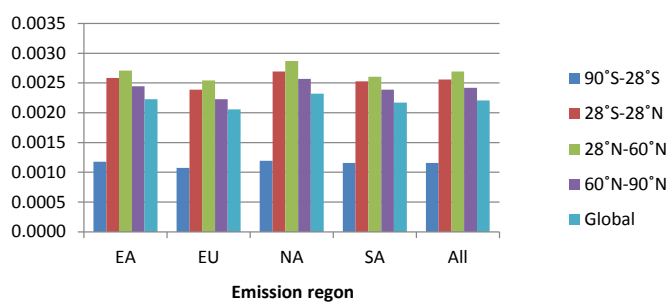

co

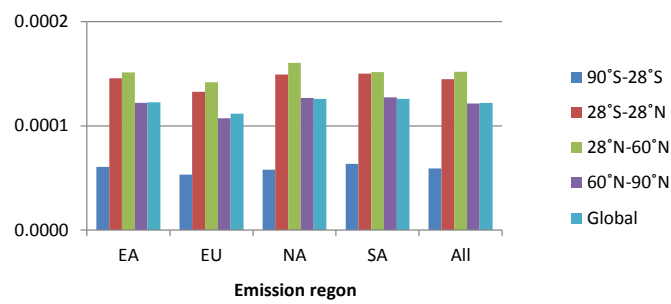

Fig. 8. $\mathrm{ARTP}(20)$ and $\mathrm{ARTP}(100)$ in $\mathrm{mK} / \mathrm{Tg}$ for emissions of $\mathrm{NO}_{\mathrm{x}}$, VOC and $\mathrm{CO}$ from the four HTAP continents. The coloured columns represent the temperature responses in 4 different latitude bands $\left(90^{\circ} \mathrm{S}-28^{\circ} \mathrm{S}, 28^{\circ} \mathrm{S}-28^{\circ} \mathrm{N}, 28^{\circ} \mathrm{N}-60^{\circ} \mathrm{N}, 60^{\circ} \mathrm{N}-90^{\circ} \mathrm{N}\right)$ and globally.

direct effect for hydrophilic aerosols (sulphate and POM in this study) and may also be important for BC. The indirect effects are likely to vary with emission region depending on their proximity to stratiform clouds and the regional aerosol loading. The impact of $\mathrm{BC}$ deposition on snow albedo is also very uncertain. Bond et al. (2011) estimate that it adds about $20 \%$ to the RF for $\mathrm{BC}$ emissions from NA, EU and SA, and about $10 \%$ for EA emissions. This might be expected to preferentially increase the temperature responses in the Arctic latitudes.

\subsection{Nitrate aerosols}

$\mathrm{NO}_{\mathrm{x}}$ emissions have an additional cooling effect by generating ammonium nitrate aerosols in regions of high ammonia abundance. Unfortunately, nitrate aerosols were not included in many of the HTAP simulations, but we can use the results of Bauer et al. (2007) who calculated a normalised direct RF from global anthropogenic $\mathrm{NO}_{\mathrm{x}}$ emissions of $-2.0 \times 10^{-12}$ $\mathrm{Wm}^{-2} \mathrm{~kg}^{-1}$. This would add -25 and -3.3 to the "All" $\mathrm{NO}_{\mathrm{x}}$ GTP(20) and (100) and (-62 and -2.2 in Table 2), making these consistently negative.

\section{$5.4 \mathrm{CO}_{2}$ from methane oxidation}

Methane is oxidised in the atmosphere, with a molar fraction $\varepsilon$ of between 0.5 and 1.0 resulting in $\mathrm{CO}_{2}$ (Boucher et al., 2009). This provides an emission of $\mathrm{CO}_{2}$ equal to $\varepsilon \times(44 / 16) \times\left[\mathrm{CH}_{4}\right] / \alpha \mathrm{CH}_{4}$ which has its own climate impact (the factor $44 / 16$ converts from a molar fraction to a mass fraction). Thus the addition to the methane GTP is:

$$
\begin{aligned}
& \Delta \mathrm{AGTP}_{\text {oxidation }}^{\mathrm{CH}_{4}}=\int_{0}^{H} \varepsilon \times \frac{44}{16} \times \\
& \frac{1}{\alpha^{\mathrm{CH}_{4}}} \exp \left(-\frac{t}{f \alpha^{\mathrm{CH}_{4}}}\right) \mathrm{AGTP}^{\mathrm{CO}_{2}}(H-t) d t
\end{aligned}
$$

The methane oxidation adds $1.3 \pm 0.4$ and $2.1 \pm 0.7$ to the GTP(20) and GTP(100) respectively as in Boucher et al. (2009). Note that for non-fossil methane this extra $\mathrm{CO}_{2}$ is still produced as described above, but should be compensated for by previous uptake of $\mathrm{CO}_{2}$. Thus the above correction should not be applied to non-fossil methane without also accounting for the uptake, requiring detailed life-cycle analysis (for instance of the production of cattle fodder).

\subsection{Carbon cycle effects}

Changes to the atmospheric composition of gases and aerosols can also affect the carbon cycle thus adding further indirect climate impacts (e.g. Sitch et al., 2007). Collins et al. (2010) showed that adding in the effects of surface ozone on vegetation damage and reduced uptake of $\mathrm{CO}_{2}$ added about $10 \%$ to the methane GTP(20) and could change the sign of the $\mathrm{NO}_{\mathrm{x}}$ GTPs. Hence the sign of the net impact of $\mathrm{NO}_{\mathrm{x}}$ emissions is still uncertain.

The temperature changes calculated in the GTPs can also lead to an impact on the carbon cycle, for instance through increased soil respiration. The above calculations of GWP and GTP for species $i$ as ratios $\mathrm{AGWP}^{i} / \mathrm{AGWP}^{\mathrm{CO}} 2$ and $\mathrm{AGTP}^{i} / \mathrm{AGTP}^{\mathrm{CO}_{2}}$ treat this inconsistently (as do many other 


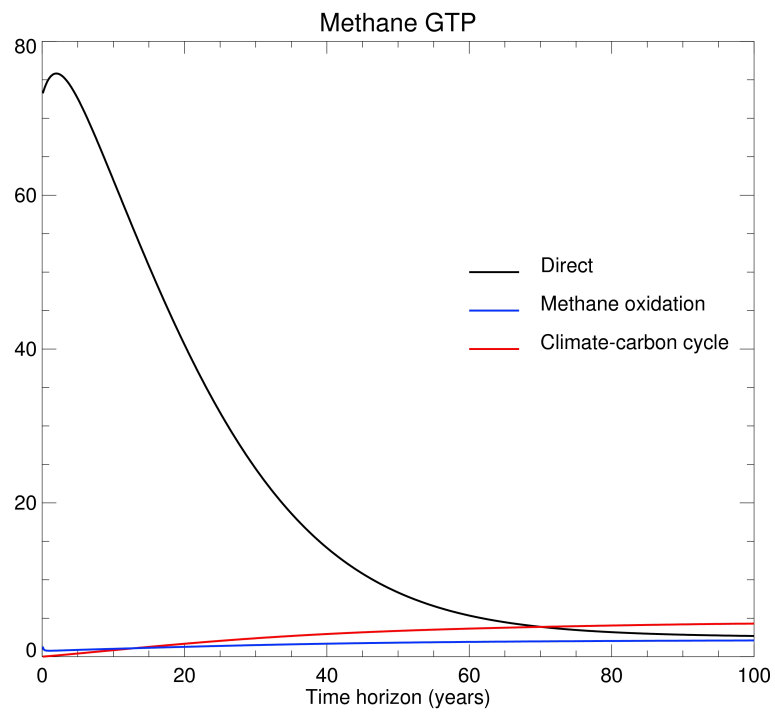

Fig. 9. The direct methane GTP (excluding ozone, sulphate and stratospheric water vapour), and additional contributions from $\mathrm{CO}_{2}$ from two sources: the atmospheric oxidation of methane; and the impact of the methane-induced temperature change on the carbon cycle.

studies, e.g. Forster et al., 2007). The temperature-carbon cycle feedback is implicitly included in the response function used for $\mathrm{CO}_{2}$ (Joos et al., 2001) and hence in the denominator $\mathrm{AGTPCO}_{2}$, but is excluded in the numerator AGTP $^{i}$. Gillett and Matthews (2010) and Sarofim (2012) using carbon cycle models find that this can underestimate the GTPs for methane by $20 \%$. A way of obtaining a simple estimate of this effect is to make the crude assumption that the change in the land-atmosphere flux of $\mathrm{CO}_{2}$ is linearly proportionally to the surface temperature change with a coefficient $\Gamma$. Multi-model comparisons of carbon cycle models (Friedlingstein et al., 2006; Arora et al., 2013) suggest a change in the land and ocean uptake of approximately

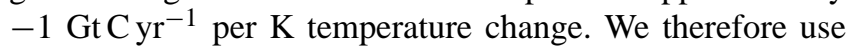
a $\Gamma$ of $+(44 / 12) \times 10^{12} \mathrm{~kg}\left(\mathrm{CO}_{2}\right) \mathrm{yr}^{-1} \mathrm{~K}^{-1}$. We associate an uncertainty of $100 \%$ with this to reflect a range from no effect to twice what we have quoted. Treating the decreased uptake as an extra $\mathrm{CO}_{2}$ release of $\Gamma \times \mathrm{AGTP}^{i}$ gives an addition to the AGTP due to the climate-carbon cycle feedback of:

$\Delta \mathrm{AGTP}_{\text {climate }}^{i}=\int_{0}^{H} \Gamma \times \operatorname{AGTP}^{i}(t) \times \operatorname{AGTP}^{\mathrm{CO}_{2}}(H-t) d t$

Note that because the $\mathrm{AGTP}^{\mathrm{CO}_{2}}$ does include the climate feedback we do not need to iterate this calculation any further. The contributions to the methane GTP from methane oxidation and climate-carbon cycle feedback are illustrated in Fig. 9 along with the direct methane impact (i.e. excluding ozone, sulphate and stratospheric water vapour). The climate-carbon cycle feedback effects are potentially large adding $1.7 \pm 1.7$ and $4.3 \pm 4.3$ to the methane GTPs at 20 and $100 \mathrm{yr}$ (55 and 3.6 in Table 2). Note that the climate-carbon cycle feedback will also affect GWPs too, adding $4.5 \pm 4.5$ to the methane GWP(100) value (24.2 in Fry et al., 2012). For aerosols and the short-term component of ozone precursors this climate-carbon cycle feedback could add $17 \%$ and $170 \%$ to the 20 and $100 \mathrm{yr}$ GTPs and $4 \%$ and $20 \%$ to the 20 and $100 \mathrm{yr}$ GWPs. The $\mathrm{CO}_{2}$ impacts are more important over longer timescales as they persist for considerably longer than the direct effects, since $\mathrm{CO}_{2}$ continues to be released for some time after the pulse of the original emitted species has decayed.

\subsection{Temperature response}

One major uncertainty is in the assumptions about the temperature response, both the timescales of the temperature response function $R$ and the latitudinal patterns included in the $\mathrm{k}_{l m}$. Oliié and Peters (2012) explore the sensitivity of GTP to model spread in $R$ and find that uncertainties increase with time horizon and decrease with lifetime. For $\mathrm{GTP}^{\mathrm{CH}_{4}}$ an uncertainty of $-12 /+10 \%$ was found for a $20 \mathrm{yr}$ time horizon, which increased to $-77 /+75 \%$ for a time horizon of $100 \mathrm{yr}$ (for 5th-95th percentiles). Higher uncertainty ranges were calculated for short-lived species such as aerosols; for $20 \mathrm{yr}$ time horizon these were $-59 /+85 \%$ and $-88 /+80 \%$ for $100 \mathrm{yr}$.

\section{Conclusions}

We have examined the climate impacts of aerosols and reactive gases, characterising them using metrics to inform policy makers of the relative importance of the different species, the dependence of impacts on emissions location, and the potential impacts of control policies. The analytical formulae constructed here could be used to calculate metrics for similar experiments in the literature (or yet to be performed) that report RFs and methane lifetime changes.

For the aerosol species the chain from RF to GWP to GTP adds little extra information on the relative differences since they are simply scalings of each other. Hence the relative global importance of emissions of different species from different regions remains unchanged from Yu et al. (2013). The inter-model variability is larger than the variability between emission regions, suggesting that a single metric averaged over all emitting regions would be a usable approximation. The small differences between regions that are suggested are a lower climate impact for the emission of $\mathrm{SO}_{2}$ and $\mathrm{POM}$ from East Asia, and a higher climate impact for the emission of BC from Europe.

We calculate $\mathrm{GTP}^{\mathrm{CH}_{4}} \mathrm{~s}$ of $56 \pm 9$ and $3.7 \pm 1.2$ for 20 and $100 \mathrm{yr}$ after including a correction for the expected increases in lower stratospheric ozone. Adding in the effects of 
climate-carbon cycle feedbacks and $\mathrm{CO}_{2}$ from methane oxidation would increase these to $59 \pm 9$ and $10.1 \pm 4.5$.

For ozone precursors, the relative importance of the short and long-term components varies with the time horizon used. This is most noticeable for $\mathrm{NO}_{\mathrm{x}}$ emissions where the short and long-term components act in opposite directions so the $\mathrm{GTP}^{\mathrm{NO}_{\mathrm{x}}} \mathrm{S}$ are dominated by the negative methane component on the $20 \mathrm{yr}$ timescale, but after $100 \mathrm{yr}$ the ozone component plays a more significant role. As with the GWPs (Fry et al., 2012), the GTPs for the ozone precursors are largely independent of source region for emissions in the northern mid-latitudes, with larger magnitudes for $\mathrm{NO}_{\mathrm{x}}$ and $\mathrm{VOC}$ emissions from the more tropical SA region due to more active photochemistry.

The different patterns of responses when moving down the impact chain become more apparent when breaking down the temperature changes into latitude bands. There is no direct relationship between the RF in a region and the surface temperature change in that region. Even when using broad latitude bands, there are contributions to the surface temperature from RF outside the region, although that contribution decreases with latitudinal distance. Thus, the latitudinal temperature patterns can differ significantly from the global mean, and also from the latitudinal forcing patterns.

The RF from sulphate and POM aerosols peaks strongly over the latitudes of the emissions, and so the northern midlatitude temperature response to northern mid-latitude emissions is approximately twice as large as the global average. For BC there is a large RF component over the Arctic; however this leads to a cooling of the Artic surface. Therefore the Arctic temperatures are most sensitive to emissions from SA since a larger proportion of $\mathrm{BC}$ emitted from the other more northerly regions is advected to the Arctic upper troposphere. This excludes the effects on Artic temperatures expected from $\mathrm{BC}$ deposition to snow which might increase the importance of the more northerly emission regions on the Arctic.

The RFs and RTPs for $\mathrm{CH}_{4}$, VOC and $\mathrm{CO}$ emissions show smoother latitudinal profiles than for the aerosols with a typically $20-30 \%$ greater temperature response in the northern mid-latitudes than the global average. $\mathrm{NO}_{\mathrm{x}}$ emissions from the Northern Hemisphere source regions lead to negative RFs in the Southern Hemisphere and the tropics and positive RFs in the northern mid-high latitudes. The resulting temperature changes however are cooling in all latitudes, with the exceptions of northern mid-latitude responses to EA and NA emissions on the $100 \mathrm{yr}$ timescale (although the $100 \mathrm{yr}$ responses are extremely small).

The findings in this paper begin to address important policy questions of whether emissions controls within a region have a larger climate effect in that region, and whether NTCF mitigation controls can be optimised for their impacts on vulnerable regions such as the Arctic.
Acknowledgements. This work was funded under the EU FP7 project ECLIPSE. W. Collins was supported by the Joint DECC/Defra Met Office Hadley Centre Climate Programme (GA01101) and the Defra contract AQ0902. H. Yu was supported by NASA grant NNX11AH66G, managed by R. Eckman. J. S. Fuglestvedt's contribution was partially funded by the Norwegian Research Council within the project "Climate and health impacts of Short-Lived Atmospheric Components (SLAC)". M. Fry was supported by the US EPA Science to Achieve Results (STAR) Graduate Fellowship Program. D. Shindell acknowledges support from NASA MAP and ACMAP.

Edited by: J. Quaas

\section{References}

Arora, V., Boer, G., Friedlingstein, P., Eby, M., Jones, C., Christian, J., Bonan, G., Bopp, L., Brovkin, V., Cadule, P., Hajima, T., Ilyina, T., Lindsay, K., Tjiputra, J., and Wu, T.: Carbonconcentration and carbon-climate feedbacks in CMIP5 Earth system models, J. Climate, doi:10.1175/JCLI-D-12-00494.1, 2013.

Bauer, S. E., Koch, D., Unger, N., Metzger, S. M., Shindell, D. T., and Streets, D. G.: Nitrate aerosols today and in 2030: a global simulation including aerosols and tropospheric ozone, Atmos. Chem. Phys., 7, 5043-5059, doi:10.5194/acp-7-5043-2007, 2007.

Berntsen, T. K., Fuglestvedt, J. S., Joshi, M. M., Shine, K. P., Stuber, N., Ponater, M., Sausen, R., Hauglustaine, D. A., and Li, L.: Climate response to regional emissions of ozone precursors: sensitivities and warming potentials. Tellus 57B, 283-304, 2005

Berntsen, T., Fuglestvedt, J., Myhre, G., Stordal, F., and Berglen, T. F.: Abatement of greenhouse gases: does location matter?, Clim. Change, 74, 377-411, 2006.

Bond, T. C., Zarzycki, C., Flanner, M. G., and Koch, D. M.: Quantifying immediate radiative forcing by black carbon and organic matter with the Specific Forcing Pulse, Atmos. Chem. Phys., 11, 1505-1525, doi:10.5194/acp-11-1505-2011, 2011.

Boucher, O. and Reddy, M. S.: Climate trade-off between black carbon and carbon dioxide emissions, Energy Pol., 36 193-200, 2008.

Boucher, O., Friedlingstein, P., Collins, W. J., and Shine, K. P.: Indirect GWP and GTP due to methane oxidation, Environ. Res. Lett., 4, 044007, doi:10.1088/1748-9326/4/4/044007, 2009.

Collins, W. J., Sitch, S., and Boucher, O.: How vegetation impacts affect climate metrics for ozone precursors, J. Geophys. Res., 115, D23308, doi:10.1029/2010JD014187, 2010.

Felzer, B. S., Cronin, T., Reilly, J. M., Melillo, J. M., and Wang, X. D.: Impacts of ozone on trees and crops, Compt. Rend. Geosci., 339, 784-798, doi:10.1016/j.crte.2007.08.008, 2007.

Fiore, A. M., Dentener, F. J., Wild, O., Cuvelier, C., Schultz, M. G., Hess, P., Textor, C., Schulz, M., Doherty, R. M., Horowitz, L. W., Mackenzie, I. A., Sanderson, M. G., Shindell, D. T., Stevenson, D. S., Szopa, S., Van Dingenen, R., Zeng, G., Atherton, C., Bergmann, D., Bey, I., Carmichael, G., Collins, W. J., Duncan, B. N., Faluvegi, G., Folberth, G., Gauss, M., Gong, S., Hauglustaine, D., Holloway, T., Isaksen, I. S. A., Jacob, D. J., Jonson, J. E., Kaminski, J. W., Keating, T. J., Lupu, A., Marmer, E., Montanaro, V., Park, R. J., Pitari, G., Pringle, K. Pyle, J. A., Schroeder, S., Vivanco, M. G., Wind, P., Wojcik, G., Wu, S., and Zuber 
A.: Multimodel estimates of intercontinental source-receptor relationships for ozone pollution, J. Geophys. Res., 114, D04301, doi:10.1029/2008JD010816, 2009.

Flanner, M. G.: Arctic climate sensitivity to local black carbon, J. Geophys. Res., doi:10.1002/jgrd.50176, 2013.

Forster, P., Ramaswamy, V., Artaxo, P., Berntsen, T., Betts, R., Fahey, D., Haywood, J., Lean, J., Lowe, D., Myhre, G., Nganga, J., Prinn, R., Raga, G., Schulz, M., and Dorland, R. V.: Changes in Atmospheric Constituents and in Radiative Forcing, in: Climate Change 2007: The Physical Science Basis. Contribution of Working Group I to the Fourth Assessment Report of the Intergovernmental Panel on Climate Change, edited by: Solomon, S., Qin, D., Manning, M., Chen, Z., Marquis, M., Averyt, K. B., Tignor, M., and Miller, H. L., Cambridge University Press, Cambridge, United Kingdom and New York, NY, USA, 2007.

Friedlingstein, P., Cox, P., Betts, R., Bopp, L., von Bloh, W., Brovkin, V., Cadule, P., Doney, S., Eby, M., Fung, I., Bala, G., John, J., Jones, C., Joos, F., Kato, T., Kawamiya, M., Knorr, W., Lindsay, K., Matthews, H. D., Raddatz, T., Payner, P., Reick, C., Roeckner, E., Schnitzler, K. G., Schnur, R., Strassmann, K., Weaver, A. J., Yoshikawa, C., and Zeng, N.: Climate-carbon cycle feedback analysis, results from the C4MIP model intercomparison. J. Climate, 19, 3337-3353 doi:10.1175/JCLI3800.1, 2006.

Fry, M. M., Naik, V., West, J. J., Schwarzkopf, M. D., Fiore, A. M., Collins, W. J., Dentener, F. J., Shindell, D. T., Atherton, C., Bergmann, D., Duncan, B. N., Hess, P., MacKenzie, I. A., Marmer, E., Schultz, M. G., Szopa, S., Wild, O., and Zeng, G..: The influence of ozone precursor emissions from four world regions on tropospheric composition and radiative climate forcing, J. Geophys. Res., 117, D07306, doi:10.1029/2011JD017134, 2012.

Fuglestvedt, J. S., Berntsen, T. K., Isaksen, I. S. A., Mao, H. T., Liang, X. Z., and Wang, W. C.: Climatic forcing of nitrogen oxides through changes in tropospheric ozone and methane; global 3D model studies, Atmos. Environ., 33, 961977, doi:10.1016/S1352-2310(98)00217-9, 1999.

Fuglestvedt, J. S., Shine, K. P., Berntsen, T., Cook, J., Lee, D. S., Stenke, A., Skeie, R. B., Velders, G. J. M., and Waitz, I. A.: Transport impacts on atmosphere and climate: metrics, Atmos. Environ., 44, 4648-4677, doi:10.1016/j.atmosenv.2009.04.044, 2010.

GFDL Global Atmospheric Model Development Team (GAMDT): The new GFDL global atmosphere and land model AM2-LM2: Evaluation with prescribed SST simulations, J. Clim., 17, 46414673, 2004.

Gillett, N. and Matthews, H.: Accounting for carbon cycle feedbacks in a comparison of the global warming effects of greenhouse gases, Environ. Res. Lett., 5, 034011, doi:10.1088/17489326/5/3/034011, 2010.

HTAP: Hemispheric Transport of Air Pollution 2010 - Part A: Ozone and Particulate Matter, Air Pollution Studies No. 17, edited by: Dentener, F., Keating, T., and Akimoto, H., United Nations, New York and Geneva, 2010.

IPCC: Climate change: The Scientific Assessment, edited by: Houghton, J. T., Jenkins, G. J., and Ephraums, J. J., Cambridge University Press, Cambridge, UK, 45-68, 1990.

IPCC: Climate change 1994: Radiative forcing of Climate Change and an Evaluation of the IPCC IS92 Emission Scenarios, edited by: Houghton, J. T., Meira Filho, L. G., Bruce, J., Lee, H., Callender, B. A., Haites, E. F., Harris, N., and Maskell, K., Cambridge University Press, Cambridge, UK, 77-127, 1994.

Koch, D., Bond, T. C., Streets, D. G., Unger, N., and van der Werf, G. R.: Global impacts of aerosols from particular source regions and sectors, J. Geophys. Res., 112, D02205, doi:10.1029/2005JD007024, 2007.

Joos, F., Prentice, I. C., Sitch, S., Meyer, R., Hooss, G., Plattner, G. K., Gerber, S., and Hasselmann, K.: Global warming feedbacks on terrestrial carbon uptake under the Intergovernmental Panel on Climate Change (IPCC) emission scenarios, Global Biogeochem. Cy., 15, 891-907, 2001.

Myhre, G., Highwood, E. J., Shine, K. P., and Stordal, F.: New estimates of radiative forcing due to well mixed greenhouse gases. Geophys. Res. Lett, 25, 2715-2718, 1998.

Naik, V., Mauzerall, D., Horowitz, L., Schwarzkopf, M. D., Ramaswamy, V., and Oppenheimer, M.: Net radiative forcing due to changes in regional emissions of tropospheric ozone precursors, J. Geophys. Res., 110, D24306, doi:10.1029/2005JD005908, 2005.

Olivié, D. J. L. and Peters, G. P.: Impact of model variation in $\mathrm{CO}_{2}$ and temperature impulse response functions on emission metrics, Earth Syst. Dynam. Discuss., 3, 935-977, doi:10.5194/esdd-3935-2012, 2012.

Prather, M. J.: Time scales in atmospheric chemistry: Theory, GWPs for $\mathrm{CH}_{4}$ and $\mathrm{CO}$, and runaway growth, Geophys. Res. Lett., 23, 2597-2600, doi:10.1029/96GL02371, 1996.

Sand, M., Berntsen, T. K., Kay, J. E., Lamarque, J. F., Seland, $\varnothing$., and Kirkevåg, A.: The Arctic response to remote and local forcing of black carbon, Atmos. Chem. Phys., 13, 211-224, doi:10.5194/acp-13-211-2013, 2013.

Sarofim, M. C.: The GTP of methane: modeling analysis of temperature impacts of methane and carbon dioxide reductions, Environ. Model. Assess., 17, 231-239, doi:10.1007/s10666-0119287-x, 2012.

Shindell, D.: Evaluation of the absolute regional temperature potential Atmos. Chem. Phys., 12, 7995-8007, doi:10.5194/acp-127955-2012, 2012.

Shindell, D. and Faluvegi, G.: Climate response to regional radiative forcing during the twentieth century, Nature Geosci., 2, 294-300, doi:10.1038/NGEO473, 2009.

Shindell, D. and Faluvegi, G.: The net climate impact of coal-fired power plant emissions, Atmos. Chem. Phys., 10, 3247-3260, doi:10.5194/acp-10-3247-2010, 2010.

Shindell, D. T., Schulz, M., Ming, Y., Takemura, T., Faluvegi, G., and Ramaswamy, V.: Spatial scales of climate response to inhomogeneous radiative forcing, J. Geophys. Res., 115, D19110, doi:10.1029/2010JD014108, 2010.

Shindell, D., Kuylenstierna, J. C. I., Vignati, E., van Dingenen, R., Amann, M., Klimont, Z., Anenberg, S. C., Muller, N., JanssensMaenhout, G., and Raes, F.: Simultaneously mitigating near-term climate change and improving human health and food security, Science, 335, 183-189, 2012.

Shine, K. P., Fuglestvedt, J. S., Hailemariam, K., and Stuber, N.: Alternatives to the global warming potential for comparing climate impacts of emissions of greenhouse gases, Clim. Change, 68, 281-302, 2005.

Sitch, S., Cox, P. M., Collins, W. J., and Huntingford, C.: Indirect radiative forcing of climate change through ozone 
effects on the land-carbon sink, Nature, 448, 791-794, doi:10.1038/nature06059, 2007.

Søvde, O., Hoyle, C., Myhre, G., and Isaksen, I.: The $\mathrm{HNO}_{3}$ forming branch of the $\mathrm{HO}_{2}+\mathrm{NO}$ reaction: pre-industrial-to-present trends in atmospheric species and radiative forcings, Atmos. Chem. Phys., 11, 8929-8943, doi:10.5194/acp-11-8929-2011, 2011.

United Nations Environment Programme and World Meteorological Organization, "Integrated Assessment of Black Carbon and Tropospheric Ozone”, Nairobi, 285 pp., 2011.

Yu, H., Dickinson, R. E., Chin, M., Kaufman, Y. J., Zhou, M., Zhou, L., Tian, Y., Dubovik, O., and Holben, B. N.: The direct radiative effect of aerosols as determined from a combination of MODIS retrievals and GOCART simulations, J. Geophys. Res., 109, D03206, doi:10.1029/2003JD003914, 2004.
Yu, H., Chin, M., West, J., Atherton, C.S., Bellouin, N., Bergmann, D., Bey, I., Bian, H., Diehl, T., Folberth, G., Hess, P., Shindell, D. T., Takemura, T., and Tan, Q.: A Hemispheric Transport of Air Pollution multi-model assessment of the influence of regional anthropogenic emission reductions on aerosol direct radiative forcing and the role of intercontinental transport, J. Geophys. Res., doi:10.1002/jgrd/20070, 2013. 